\title{
Grundtvig-Selskabet af 8. september 1947: Årsberetning 2005
}

\author{
Af Peter Balslev-Clausen
}

Grundtvig-Selskabets årsmøde 2004 blev afholdt fredag 5. november 2004 i Vartov, Farvergade 27 i København. Ved mødet, der blev afviklet med Regner Birkelund som dirigent, blev A. M. Allchin, Anders Holmberg, Erland U. Jessen, Poul Kiilerich, Flemming Lundgreen-Nielsen, Erik Jakob Petersen og Sigurd Aa. Aarnæs valgt til styrelsen og Flemming Lundgreen Nielsen, Kim Arne Pedersen og Christian Thodberg valgt til forretningsudvalget. Forretningsudvalget konstituerede sig derefter med Peter Balslev-Clausen som formand, Flemming Lundgreen-Nielsen som næstformand, Erik Jakob Petersen som kasserer, Kim Arne Pedersen som sekretær, Jens Holger Schjørring, Flemming Lundgreen-Nielsen, Kim Arne Pedersen og S. A. J. Bradley i redaktionen for Grundtvig-Studier (med Jens Holger Schjørring som ansvarshavende redaktør) og Christian Thodberg som menigt medlem. I forbindelse med årsmødet blev der holdt to foredrag. Kim Arne Pedersen talte om "Aspekter af Grundtvigs frihedssyn" og William Thomassen om "Grundtvig og asylbevægelsen".

Det udvalg, der forrige år blev nedsat til at undersøge mulighederne for at udbrede kendskabet til Grundtvig-Selskabets virksomhed, og som har selskabets formand, kasserer og sekretær som sine faste medlemmer, har i året løb arbejdet videre og blandt andet tilrettelagt det seminar, der afholdes her på Engelsholm Højskole i forbindelse med dette årsmøde i selskabet. Efter en evaluering af seminar og årsmøde vil udvalget fortsætte sine overvejelser sammen med forretningsudvalget.

Formanden for Grundtvig-Selskabets norske afdeling, Kirsti Åsen, skriver i sin rapport for året 2005, at "Lørdag 5. marts ble det avholdt et seminar om 'Grundtvig og kunsten' ved tidligere rektor ved prestehøyskolen i Løgumkloster Niels Thomsen og 1. amanuensis i filosofi ved Universitetet i Oslo Torstein Tollefsen, som holdt foredrag om Ikonkunsten. Seminaret var godt besøgt. I dagene 14.-15. september arrangerte vi - i samarbeid med Norges Kristelige folkehøgskolelag og Norsk Folkehøgskolelag - et seminar med tema 'Grenseløs og overskridende dialog'. Dette seminaret var i første rekke en invitasjon til aktive folkehøgskolefolk. Formålet var 1) at prøve å at ta et konstruktivt og reflektivt grep om den viktige debatten som har utspilt seg det siste året $\mathrm{i}$ de to [norske] folkehøgskolebladene om forholdet mellom den frilynte og kristelige folkehøgskolen. 2) at vise fram eksempler på norsk grundtvigforskning og dens betydning for

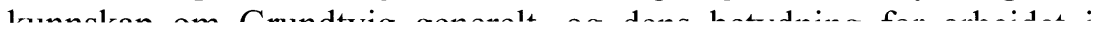


folkehøgskolen spesielt, 3) at bidra til å bekjempe den historieløsheten som kan gjøre seg gjeldene også i folkehøgskolebevegelsen, og 4) at bidra til å bekjempe tendensen til antiintellektualisme som i noen grad viser seg fram i den norske forståelsen av folkelighet. Medvirkende var Arild Mikkelsen, Tor Grønvik, Pål Walstad og Synnøve Heggem. For øvrig går arbeidet sin jevne gang med spredte og mindre arrangementer og sammenkomster - og med utgivelse av medlemsbladet to ganger i året."

Center for Grundtvigstudier ved Aarhus Universitet, der ledes af Jens Holger Schjørring og som faste medarbejdere har Anja Stokholm og Anne-Grethe Jørgensen Dion, har fortsat S. A. J. Bradley tilknyttet i forbindelse med det engelske Grundtvig-oversættelsesprojekt og Christian Thodberg og kredsen omkring ham i forbindelse med udgivelsen af Grundtvigs prædikener i 1840'erne. Foråret 2005 indbød centret til en offentlig forelæsningsrække om Grundtvig og grundtvigianismen, tilrettelagt af centrets to ph.d.-studerende, Ulrik Overgaard og Anders Holm. Forlæsere var Jørgen I. Jensen ("Introduktion til Grundtvig og grundtvigianismen"), Sune Auken ("Grundtvig og mytologien"), Anders Holm ("Historie og kristendom hos Grundtvig"), Christian Thodberg ("Grundtvigs prædikener og salmer"), Claus Bjørn ("Politikeren Grundtvig"), Kim Arne Pedersen ("Grundtvig i dansk, politisk virkningshistorie"), Ove Korsgaard ("Grundtvigs dannelsesbegreb"), Thorkild C. Lyby ("Grundtvigianismen i Danmark"), S. A. J. Bradley ("Grundtvig og England"), Asoke Bhattacharya ("Grundtvig i den 3. verden") og Henrik WighPoulsen ("At være grundtvigsk i dag").

Grundtvig-Akademiet har fortsat en aktiv mødevirksomhed, dels i Vartov i København, dels i samarbejde med andre som Tårnborg i Ribe og kursuscentret Skærum Mølle ved Vemb. 15. november 2004 afholdt Grundtvig-Akademiet i Vartov i samarbejde med Søren Kierkegaard Forskningscentret et seminar om "Tid og historie" med indlæg af Niels Henrik Gregersen ("Arvesyndslæren revideret: Grundtvig og Kierkegaard"), Ole Vind ("Eksistens eller historie? Kierkegaard og Grundtvig som modpoler") og Anders Holm ("Historien i øjeblikket og øjeblikket i historien"). 15.-17. april 2005 blev der ligeledes i samarbejde med Søren Kierkegaard forskningscentret gennemført et seminar om "Kanon-dannelse" i Vartov med indlæg af Joakim Garff ("Dannelse - hvad er det? en simpel introduktion til et kompliceret fænomen"), Ove Korsgaard ("Dannelse og duelighed. Grundtvigs begrebspar i historisk og aktuel belysning"), Marianne Zibrandtsen ("Dansk litteraturs kanon - statens bidrag til dannelsen"), Anne-Marie Eggert Olsen ("Politisk dannelse - i multikulturelt perspektiv"), Jes Fabricius Møller ("Dannelsesmiddag ifølge Emma Gad"), Marie Rørbech ("Kulturel dannelse - et praktisk eksempel") og Jens Erik Kristensen ("Dannelse i en pædagogisk, 
skolemæssig sammenhæng").

Vartov-arkivet, der rummer et omfattende arkivmateriale til belysning af Grundvigs pædagogiske virkningshistorie, og som har til huse i kælderen i Vartovs fløj mod Vester Voldgade, har fortsat konsolideret og udbygget sin virksomhed under Morten Mortensens ledelse.

Grundtvig-Biblioteket er i det år, der er gået, flyttet til andre lokaler i Vartov og har nu til huse i stueetagen i fløjen mod Farvergade, til venstre, når man kommer ind gennem porten. I øvrigt er bibliotekets virksomhed fortsat uændret et grundtvigsk videns- og dokumentationscenter under ledelse af bibliotekar Liselotte Larsen.

Grundtvig-Selskabets udgivelsesmæssige flagskib er igen $\mathrm{i}$ år årbogen Grundtvig-Studier, der under Jens Holger Schjørrings, S. A. J. Bradleys, Flemming Lundgreen-Nielsens og Kim Arne Pedersens redaktion bringer en række både aktuelle og forskningsbaserede artikler. Årbogen indledes med Johs. H. Christensens nekrolog over Ebbe Kløvedal Reich. Derefter følger S. A. J. Bradley: "To etablish a free and open forum: A memoir of the founding of the Grundtvig Society" og Christian Thodberg: "Grundtvigs krise i foråret 1844. Forholdet mellem prædiken og salme med henblik på 'Sov sødt, Barnlille'. Jette Holm, Elisabeth A. Glenthøj og Christian Thodberg aftrykker i forbindelse hermed "Grundtvigs prædiken i Vartov 1. maj 1844" og Jette Holm supplerer med "Breve til og fra Grundtvig, marts - juni 1844". Kim Arne Pedersen skriver om "Grundtvig og fundamentalismen" og Regner Birkelund om "Kend dig selv: Om det sociale individ og det sunde samfund". Thorkild C. Lyby omtaler Sune Aukens Grundtvig-disputats i artiklen "Odin og Hvide Krist: Om Sune Aukens bog Sagas spejl. Mytologi, historie og kristendom hos N. F. S. Grundtvig, København, 2005". K. E. Bugge skriver om "Grundtvig and the abolition of slavery", Asoke Bhattacharya om "N. F. S. Grundtvig. Educationalist extraordinary", Jes Fabricius Møller om "Friheden og ligheden", Erik Kelstrup "Om Gud først og sidst", Agnieszka Bron om "Alive and well in Eastern Europe: A review" og A. M. Allchin om "Grundtvig's Vartov Sermons: An appreciation". Grundtvig-Studier kaldes nu på andet år på omslaget "An International journal for the Study of Nicolai Frederik Severin Grundtvig (17831872)".

Som indholdsoversigten viser, indeholder årbogen flere engelsksprogede artikler ud over summaries ligeledes på engelsk. Grundtvigstudiet er i dag ikke forbeholdt dansksprogede forskere og læsere. I takt med udgivelsen af tekstudvalg på både tysk og engelsk må det forudses, at den internationale interesse for studiet af Grundtvig vil vokse og dermed behovet for engelsksprogede artikler i Grundtvigselskabets årbog. Det er en udvikling, der kun kan hilses velkommen, for så vidt som den vidner om interessen for Grundtvig-studiet, og med 
den udbredelse, kendskabet til engelsk har i Danmark i dag, vil brugen af engelsk næppe virke fremmedgørende på danske læsere af Grundtvig-Studier.

I årets løb er to Grundtvig-afhandlinger forsvaret for doktorgraden. 16. april forsvarede Synnøve Sakura Heggem afhandlingen Kjoerlighetens makt, maskerade og mosaikk - En lesning af N. F. S. Grundtvigs Sang-Vark til den Danske Kirke for den teologiske doktorgrad på Oslo Universitet, og 3. juni forsvarede Sune Auken afhandlingen Sagas spejl. Mytologi, historie og kristendom hos N. F. S. Grundtvig for den filosofiske doktorgrad på Københavns Universitet.

Derudover har Jes Fabricius Møller i Grundtvigianismen $i$ det 20. århundrede givet en skildring af den grundtvigske inspirations virkningshistorie gennem 19. århundrede, og Bjarne Nielsen Brovst har med Den unge Grundtvigs lidelser fortsat sin biografiske skildring af Grundtvigs slægt, hans barndom og ungdom, som han begyndte i Grundtvigs Slagt og Barndom og Den unge Grundtvig og en familietragedie.

De to store oversættelsesprojekter til tysk og engelsk skrider planmæssigt frem. Det tyske projekt ved K. E. Bugge, Flemming Lundgreen-Nielsen og Theodor Jørgensen nærmer sig sin afslutning, og det engelske ved S. A. J. Bradley er ved at være nået halvvejen.

I lighed med tidligere år er også i år Vartovbogen et vigtigt udtryk for og nedslag af den grundtvigske virkningshistorie. Årbogen, der redigeres af Jørgen Carlsen, Hans Kelstrup, Henning Nielsen og Henrik Wigh-Poulsen, indeholder bidrag af Birthe Rønn Hornbech ("Gud og politik"), Thomas Reinholt Rasmussen ("Et kristent menneskes frihed - om Martin Luther og de to regimenter"), Ida Auken ("Kunsten at skelne - om de to regimenter"), Anders Hjort ("Det radikale Venstre og kirke-stat debatten"), Morten Kvist ("Arvesynd og politik"), Svend Søndergaard ("Islam - Gud og politik"), Elof Westergaard ("Tyrkiet på vej mod EU og mere religion"), Sørine Gotfredsen ("Vejen til den danske åndelighed"), Bente Clausen ("En kirke på vej mod verdens vildnis"), Hans Hauge ("Kulturkamp og religionskrig"), Niels Højlund ("Systemskifte Uddrag fra bogen Bedre end fortjent") og Poul Engberg ("Dette her grundtvigske").

Det udredningsarbejde vedrørende en udgivelse af Grundtvigs skrifter, som Kirkeligt Samfund har sat i gang, og som blev omtalt i sidste års beretning, er fortsat. Kim Arne Pedersen har som deltidsansat akademisk arbejdskraft været beskæftiget med beregningen af omfanget af en videnskabelig Grundtvig-udgave. Han har været under tilsyn af et udredningsudvalg bestående af Jens Holger Schjørring (formand), Henrik Wigh-Poulsen (sekretær), Ove Korsgaard, Theodor Jørgensen, Hans Raun Iversen, Niels Henrik Gregersen, Flemming Lundgreen-Nielsen, Peter Balslev-Clausen, Sune Auken, K. E. Bugge, 
formanden for Kirkeligt Samfund, formanden for GrundtvigAkademiet samt et medlem af Kirkeligt Samfunds Styrelse. Niels Jørgen Cappelørn fungerer som konsulent for udredningsarbejdet. En styringsgruppe, der skal varetage forbindelsen mellem udredningsudvalget og Kim Arne Pedersen, består af Benneth Østergaard, Hans Grishauge, Inge Lise Pedersen og Henrik Wigh-Poulsen. Der har været afholdt et par møder i udredningsgruppen i årets løb, og det overvejes, hvor stort omfanget af udgivelsen skal være, om udgivelsen skal omfatte alt trykt i Grundtvigs levetid, eventuelt suppleret med det, der er trykt siden Grundtvigs død, eventuelt yderligere suppleret med væsentlige endnu ikke udgivne manuskripter. Det ventes, at den endelige udgivelsesplan vil være klar i første halvår af 2006, hvorefter der vil ske henvendelse til relevante fonde om støtte til udgivelsesarbejdet. Det har i forbindelse med drøftelserne af udgivelsesprojektet været nævnt, at det kunne være ønskeligt med en mindre studieudgave af Grundtvigs skrifter ved siden af den store, samlede videnskabelige udgivelse.

Et tegn på, at en udgave af Grundtvigs skrifter er påkrævet, viser den diskussion, der med mellemrum føres i offentligheden om Grundtvigs betydning, og om hvor relevant inspirationen fra Grundtvigs tanker er. I maj og juni i år blev der i dagbladet Berlingske Tidende ført en debat, hvor en lang række højskolefolk, politikere, journalister og kulturdebattører diskuterede forholdet mellem højskolen, inspirationen fra Grundtvig og Venstre, Danmarks liberale Parti. Det indtryk, der stod tilbage efter debatten var, at deltagerne i debatten i høj grad talte forbi hinanden. En del af debatdeltagerne var godt orienterede om Grundtvig, andre var det ikke, og om ikke andet afslørede debatten behovet for opdateret viden om Grundtvig og hans syn på menneske- og folkelivets vilkår. Det må være GrundtvigSelskabets mål at medvirke til en sådan opdatering af kendskabet til Grundtvig. Tekst- og værkudgivelser kan være en af vejene, det samme kan seminarer som det, der $\mathrm{i}$ går og $\mathrm{i}$ dag har fundet sted $\mathrm{i}$ forbindelse med Grundtvig-Selskabets årsmøde. Der er nok at gå i gang med for alle, og som det er fremgået af denne beretning, er der mange, der er engagerede i studiet og formidlingen af Grundtvigs forfatterskab og dermed hans syn på menneske- og folkelivet!

Også i år skal der fra Grundtvig-Selskabets årsmøde lyde en tak til alle, der på forskellig vis har hjulpet selskabet $\mathrm{i}$ årets løb. Ansatte på Center for Grundtvigstudier ved Aarhus Universitet, på GrundtvigAkademiet, Grundtvig-Biblioteket og Vartov-Arkivet i København. Dertil kommer Kirkeligt Samfund repræsenteret ved formanden, Jens Bruun, og sekretariatsleder i Vartov Hans Grishauge sammen med sekretær Kirsten Grishauge. Forskningsrådet for Kultur og Kommunikation skal takkes for støtte til udgivelsen af Grundtvig-Studier, og Engelsholm Højskole skal have tak for et engageret værtskab for og 
samarbejde i forbindelse med det seminar, "Højskolen i vadestedet ...", som dette årsmøde danner afslutningen på. Først og sidst skal alle Grundtvig-Selskabets medlemmer i Danmark, Norge og resten af verden takkes for trofast støtte til og engageret medarbejde ved "studiet af N. F. S. Grundtvig, hans virke og hans stilling $\mathrm{i}$ åndslivet $\mathrm{i}$ og udenfor Danmark". 